\title{
Effect of Calcium Phosphate Nanoparticles Supplementation on Growth Performance of Broiler Chicken
}

\author{
M. P. Vijayakumar* and V. Balakrishnan \\ Department of Animal Nutrition, Madras Veterinary College, Chennai-600 007, Tamil Nadu, India; \\ vijinutrition@gmail.com, drbalakrishnanphd@yahoo.co.in
}

\begin{abstract}
The supplementation of mineral in nano form increases bioavailability and efficiency of utilisation. In this context an experiment was carried out to study the effect of calcium phosphate nanoparticles supplementation on the growth performance of broilers with the objective to reduce the quantity of mineral supplementation that would intern reduce the feed cost. Since phosphorus is expensive among the mineral sources, its requirement as dicalcium phosphate was replaced by nano form of calcium phosphate as low as 50\% requirement to $100 \%$ at $10 \%$ increment range. Calcium phosphate nanoparticles were synthesised in laboratory by wet chemical method and the particle size and morphology were determined using transmission electron microscope. Calcium phosphate nanoparticles ranged between 20 and 90 $\mathrm{nm}$. Feeding trail was conducted using mash feed. Feeding trial in 70 male broiler chicks (Cobb 400) from day 1 to 28 indicated that the cumulative feed intake was significantly ( $\mathrm{p}<0.05)$ higher $(1487.30 \pm 19.99,1510.80 \pm 13.82,1549.30 \pm$ $5.75,1550.00 \pm 3.52,1562.50 \pm 3.85$ and $1572.80 \pm 1.50 \mathrm{~g}$ ) in birds fed with calcium phosphate nanoparticles at 50, 60, $70,80,90$ and $100 \%$ respectively in the diet than control diet containing coarse particles of dicalcium phosphate (1466.60 $\pm 4.73 \mathrm{~g}$ ). By the end of fourth week, birds fed with $50 \%$ and $60 \%$ calcium phosphate nanoparticles had significantly $(\mathrm{p}<0.05)$ higher bodyweight gain $(1069.90 \pm 9.31$ and $1068.50 \pm 36.51)$ respectively than control $(891.60 \pm 48.1 \mathrm{~g})$. Birds fed with $50 \%$ calcium phosphate nanoparticles recorded best feed conversion ratio (1.39 \pm 0.02$)$ and it differed significantly $(\mathrm{p}<0.05)$ from control $(1.64 \pm 0.08)$ group. It is concluded that supplementation of $50 \%$ of calcium phosphate nanoparticles can be practiced instead of the conventional practice of dicalcium phosphate incorporation in broilers diet. Thus, it is postulated that the usefulness of nano form in reducing the mineral quantity to half in the diet will reduce the cost of feeding when the actual production of calcium phosphate nanoparticles is up scaled to an industrial level.
\end{abstract}

Keywords: Broiler Chicken, Calcium Phosphate Nanoparticles, Performance

\section{Introduction}

In the recent past various strategies have been explored to reduce the feed cost of poultry by reducing the cost of mineral supplementation. The ways for exploring methodologies for enhancing bioavailability of minerals especially calcium and phosphorus is a strategy to reduce the poultry feed cost. Nano form of supplementation increases the surface area which possibly could increase absorption $^{1}$ and thereby utilization of minerals leading to reduction in the quantity of supplements and ultimately reduction in feed cost. The growing concerns with regard to the potential contribution of phosphorus in poultry excreta on eutrophication of surface waters has led to increasing pressure to limit the amount of excess phosphorus in poultry ration and thus reduce faecal output of phosphorus ${ }^{2}$. Mineral nanoparticles will be helpful in reducing the excretion of unutilized minerals, thereby

*Author for correspondence 
minimizing the environmental pollution especially in large scale poultry farming.

With this background, the effect of calcium phosphate nano particles supplementation on the performance of broiler chicken was studied.

\section{Materials and Methods}

Calcium phosphate nanoparticles for the experiment was prepared by wet chemical method ${ }^{3}$ wherein an aqueous solution of calcium nitrate $(18 \mathrm{mM})$ was prepared and mixed with an aqueous solution of diammonium hydrogen phosphate $(10.8 \mathrm{mM})$. The $\mathrm{pH}$ of both the solutions was adjusted to 9 using $0.1 \mathrm{M}$ sodium hydroxide prior to mixing. The mixture of solutions were centrifuged at $12000 \mathrm{rpm}$ and the particles were allowed to settle at the bottom which was then spread out as a thin film in trays and dried in hot air oven at $90^{\circ} \mathrm{C}$. After drying white soft powder (calcium phosphate nanoparticles) was obtained using an indigenously fabricated unit.

The size and morphology of the prepared calcium phosphate nanoparticles was carried out by adopting the procedure of4, using Transmission Electron Microscopy (TEM) (Figure 1).

Calcium phosphate nanoparticles had spherical shape with diameter measuring between 20 and 90 nanometers.

Seventy day old male broiler chicks (cobb- 400) belonging to a single hatch were purchased from a commercial farm were wing banded, weighed individually and distributed randomly to the seven experimental groups

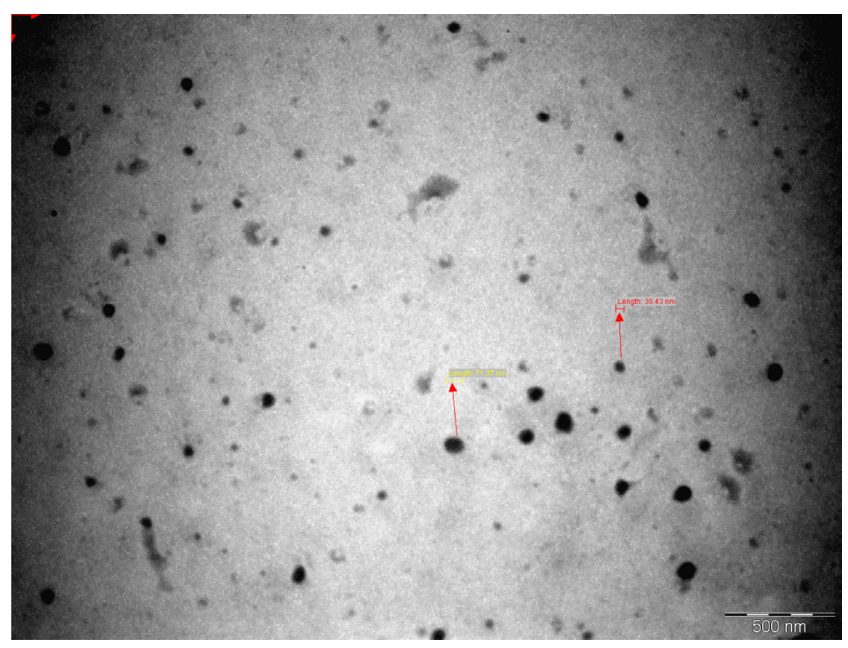

Figure 1. Transmission electron microscopic view of spherical shape of dispersed calcium phosphate nanoparticles. of 10 chicks each. The experimental birds were housed individually in five tiered, well ventilated battery cages provided with artificial lighting. The management practices adopted were as per the standards and were uniform for all the treatment groups. Wherein graded levels of calcium phosphate nanoparticles were included for 28 days. Dicalcium phosphate and calcite were used in control diet. The phosphorus content in dicalcium phosphate was replaced at graded level by nano form of calcium phosphate at 50 to $100 \%$ at $10 \%$ interval. The treatment of $50 \%$ calcium phosphate nanoparticles means a $50 \%$ less than the phosphorous contribution as dicalcium phosphate $(\mathrm{w} / \mathrm{w})$ supplemented in control treatment. In this experiment, 60, 70, 80, 90 and $100 \%$ calcium phosphate nanoparticle mean, a 40, 30, 20, 10 and $0 \%$ less phosphorous contribution as dicalcium phosphate supplemented in control respectively. The details of the various experimental groups are furnished in Table 1.

The per cent ingredient and nutrient composition of experimental rations are presented in Table 2.

The birds were fed ad libitum quantity of their respective experimental rations in separate feed troughs in mash form. The left over feed and wastage were weighed every day so as to record the accurate feed intake. Clean drinking water was provided ad libidum.

The birds were weighed individually once in a week in a calibrated balance to document their weight gains. The feed conversion ratio of individual birds was calculated at 28 days by dividing the total feed consumed $(\mathrm{kg})$ per bird with its respective cumulative body weight gain $(\mathrm{kg})$.

\section{Results and Discussion}

The data on mean feed consumption (g) per bird on weekly intervals as influenced by various levels of calcium phosphate nanoparticles is presented in Table 3. The dietary groups fed with different levels of calcium phosphate nanoparticles differed significantly $(p<0.05)$ in the first week of feed consumption itself. Chicks fed with 50 (T1), 60 (T2), 70 (T3), 80 (T4), 90 (T5) and 100 (T6) per cent calcium phosphate nanoparticles consumed 116.40 $\pm 0.62,115.00 \pm 0.50,114.80 \pm 0.62,117.50 \pm 2.50,111.80$ \pm 2.76 and $114.30 \pm 2.49 \mathrm{~g}$ of feed respectively during their first week of age, whereas birds fed with control feed consumed only $87.40 \pm 1.77$ g feed which was significantly $(\mathrm{p}<0.05)$ lower than the feed intake of treatment groups containing calcium phosphate nanoparticles. Similarly, the cumulative feed intake was also found to be 
Table 1. Experimental design showing the proportion of mineral sources used to achieve respective concentration of minerals

\begin{tabular}{|c|c|c|c|c|}
\hline $\begin{array}{l}\text { Treatment } \\
\text { group }\end{array}$ & Mineral source & $\begin{array}{l}\text { Inclusion } \\
\text { level (\%) }\end{array}$ & $\begin{array}{c}\text { Phosphorus } \\
\text { contribution } \\
\text { level }(\%)\end{array}$ & $\begin{array}{c}\text { Calcium } \\
\text { contribution } \\
\text { level }(\%)\end{array}$ \\
\hline & \multicolumn{4}{|c|}{ (number in \% indicates $\mathrm{w} / \mathrm{w}$ ) } \\
\hline \multirow{3}{*}{$\begin{array}{l}\text { Control } \\
100 \% \\
\text { dicalcium phosphate }\end{array}$} & $\begin{array}{l}\text { Dicalcium } \\
\text { phosphate }\end{array}$ & 1.70 & 0.2975 & 0.3910 \\
\hline & Calcite & 1.25 & 0.0000 & 0.4375 \\
\hline & Total & 2.95 & 0.2975 & 0.8285 \\
\hline \multirow{3}{*}{$\begin{array}{l}\mathrm{T} 1 \\
50 \% \text { calcium phosphate } \\
\text { nanoparticles }\end{array}$} & $\begin{array}{l}\text { Calcium phosphate } \\
\text { nanoparticles }\end{array}$ & 0.95 & 0.14706 & 0.28671 \\
\hline & Calcite & 0.75 & 0.00000 & 0.26250 \\
\hline & Total & 1.70 & 0.14706 & 0.54921 \\
\hline \multirow{3}{*}{$\begin{array}{l}\mathrm{T} 2 \\
60 \% \text { calcium phosphate } \\
\text { nanoparticles }\end{array}$} & $\begin{array}{l}\text { Calcium phosphate } \\
\text { nanoparticles }\end{array}$ & 1.14 & 0.176472 & 0.34405 \\
\hline & Calcite & 0.75 & 0.000000 & 0.26250 \\
\hline & Total & 1.89 & 0.176472 & 0.60655 \\
\hline \multirow{3}{*}{$\begin{array}{l}\text { T3 } \\
70 \% \text { calcium phosphate } \\
\text { nanoparticles }\end{array}$} & $\begin{array}{l}\text { Calcium phosphate } \\
\text { nanoparticles }\end{array}$ & 1.33 & 0.205884 & 0.40139 \\
\hline & Calcite & 0.75 & 0.000000 & 0.26250 \\
\hline & Total & 2.08 & 0.205884 & 0.66389 \\
\hline \multirow{3}{*}{$\begin{array}{l}\mathrm{T} 4 \\
80 \% \text { calcium phosphate } \\
\text { nanoparticles }\end{array}$} & $\begin{array}{l}\text { Calcium phosphate } \\
\text { nanoparticles }\end{array}$ & 1.52 & 0.235296 & 0.45874 \\
\hline & Calcite & 0.75 & 0.000000 & 0.26250 \\
\hline & Total & 2.27 & 0.235296 & 0.72124 \\
\hline \multirow{3}{*}{$\begin{array}{l}\text { T5 } \\
90 \% \text { calcium phosphate } \\
\text { nanoparticles }\end{array}$} & $\begin{array}{l}\text { Calcium phosphate } \\
\text { nanoparticles }\end{array}$ & 1.71 & 0.264708 & 0.51608 \\
\hline & Calcite & 0.75 & 0.000000 & 0.26250 \\
\hline & Total & 2.46 & 0.264708 & 0.77858 \\
\hline \multirow{3}{*}{$\begin{array}{l}\text { T6 } \\
100 \% \text { calcium } \\
\text { phosphate } \\
\text { nanoparticles }\end{array}$} & $\begin{array}{l}\text { Calcium phosphate } \\
\text { nanoparticles }\end{array}$ & 1.90 & 0.29412 & 0.57342 \\
\hline & Calcite & 0.75 & 0.00000 & 0.26250 \\
\hline & Total & 2.65 & 0.29412 & 0.83592 \\
\hline
\end{tabular}

significantly $(\mathrm{p}<0.05)$ higher in birds fed with 60,70 , 80, 90 and 100 per cent of calcium phosphate nanoparticles compared to control recorded during second, third and fourth week of age. The cumulative feed intake was observed to increase with increase in the level of supplementation of calcium phosphate nanoparticles. It was observed that the cumulative feed intake tend to increase with increase in the level of supplementation of calcium phosphorus nanoparticles from $50 \%$ to $100 \%$. Increase in feed intake is reflection of palatability. Sensory improvement due to nanoparticles has been reported by Food safety authority of Ireland ${ }^{5}$. Increase in palatability due to supplementation of calcium phosphorus nanoparticles could be attributed to sensory improvement in flavour / texture.

The data on mean weight gain $(\mathrm{g})$ in birds on weekly intervals as influenced by various levels of calcium phosphate nanoparticles is presented in Table 4. The mean weight gains $(\mathrm{g})$ in broilers in the control group were comparable to the data recorded by ${ }^{6,7}$. The dietary groups fed with different levels of calcium phosphate nanoparticles differ significantly $(\mathrm{p}<0.05)$ in terms of first week weight 
Table 2. Percent ingredient and nutrient composition of experimental rations

\begin{tabular}{|c|c|c|c|c|c|c|c|}
\hline Ingredients (\%) & Control & $\begin{array}{c}50 \% \text { calcium } \\
\text { phosphate } \\
\text { nanoparticles }\end{array}$ & $\begin{array}{c}60 \% \text { calcium } \\
\text { phosphate } \\
\text { nanoparticles }\end{array}$ & $\begin{array}{c}70 \% \text { calcium } \\
\text { phosphate } \\
\text { nanoparticles }\end{array}$ & $\begin{array}{c}80 \% \text { calcium } \\
\text { phosphate } \\
\text { nanoparticles }\end{array}$ & $\begin{array}{c}90 \% \text { calcium } \\
\text { phosphate } \\
\text { nanoparticles }\end{array}$ & $\begin{array}{c}100 \% \text { calcium } \\
\text { phosphate } \\
\text { nanoparticles }\end{array}$ \\
\hline Maize & 52.65 & 54.60 & 54.31 & 54.07 & 53.63 & 53.39 & 53.15 \\
\hline Soyabean meal & 38.50 & 38.50 & 38.50 & 38.50 & 38.50 & 38.50 & 38.50 \\
\hline Vegetable Oil & 5.00 & 4.30 & 4.40 & 4.450 & 4.70 & 4.75 & 4.80 \\
\hline $\mathrm{NaCl}$ & 0.30 & 0.30 & 0.30 & 0.30 & 0.30 & 0.30 & 0.30 \\
\hline Calcite & 1.25 & 0.75 & 0.75 & 0.75 & 0.75 & 0.75 & 0.75 \\
\hline Dicalcium phosphate & 1.70 & - & - & - & - & - & - \\
\hline $\begin{array}{l}\text { Calcium phosphate } \\
\text { nanoparticle }\end{array}$ & - & 0.95 & 1.14 & 1.33 & 1.52 & 1.71 & 1.90 \\
\hline Lysine & 0.30 & 0.30 & 0.30 & 0.30 & 0.30 & 0.30 & 0.30 \\
\hline Methionine & 0.30 & 0.30 & 0.30 & 0.30 & 0.30 & 0.30 & 0.30 \\
\hline Total & 100 & 100 & 100 & 100 & 100 & 100 & 100 \\
\hline \multicolumn{8}{|c|}{ Calculated Nutritive Value } \\
\hline $\mathrm{ME}(\mathrm{Kcal} / \mathrm{kg})$ & 3092.48 & 3096.48 & 3095.77 & 3092.23 & 3099.99 & 3096.45 & 3092.91 \\
\hline $\mathrm{CP}(\%)$ & 21.87 & 22.04 & 22.01 & 21.99 & 21.95 & 21.93 & 21.91 \\
\hline Calorie Protein ratio & 141.42 & 140.51 & 140.64 & 140.61 & 141.2 & 141.17 & 141.41 \\
\hline Lysine (\%) & 1.41 & 1.41 & 1.41 & 1.41 & 1.41 & 1.41 & 1.41 \\
\hline Methionine (\%) & 0.63 & 0.63 & 0.63 & 0.63 & 0.63 & 0.63 & 0.63 \\
\hline Calcium (\%) & 0.96 & 0.67 & 0.73 & 0.79 & 0.84 & 0.90 & 0.96 \\
\hline Phosphorus (\%) & 0.45 & 0.29 & 0.32 & 0.35 & 0.38 & 0.41 & 0.44 \\
\hline
\end{tabular}

Vitamin - Mineral premix (200/Quintal of feed)

Trace mineral premixture ( $45 \mathrm{~g} /$ Quintal)-Ferrous sulphate $2 \mathrm{~g}, \mathrm{CuSo}_{4}-1.9 \mathrm{~g}, \mathrm{ZnSo}_{4}-6 \mathrm{~g}, \mathrm{MnSO}_{4}-15 \mathrm{~g}$ and $\mathrm{KI}-100 \mathrm{mg}$

Vitamin mixture was added (10g/ Quintal): Each g contains Vit A -82500 IU,D3-120000 IU, K-10mg and B2-50 mg.

Vitamin B complex and E (25 g) - Vit $B_{1}-4$ ng, Vit $B_{6}-8$ ng, Vit $B_{12}-12$ ig, Vit E 40 IU and Niacin 60 ng.

Choline chloride $-50 \mathrm{~g}$, Maize powder as carrier

Table 3. Weekly cumulative feed consumption (g) per bird in broilers up to 4 weeks of age (Mean* \pm SE) as influenced by various levels of calcium phosphate nanoparticles

\begin{tabular}{lccccc}
\hline \multirow{2}{*}{$\begin{array}{l}\text { Treatment } \\
\text { groups }\end{array}$} & $\begin{array}{c}\text { Inclusion level of } \\
\text { Calcium phosphate } \\
\text { nanoparticles (\%) }\end{array}$ & \multicolumn{3}{c}{ Cumulative feed consumption $(\mathrm{g}) / \mathrm{bird} /$ week $\left(\mathrm{Mean}^{\star} \pm \mathrm{SE}\right)$} \\
\cline { 3 - 6 } & 0 & $87.40^{\mathrm{a}} \pm 1.77$ & $351.80^{\mathrm{a}} \pm 2.44$ & $823.40^{\mathrm{a}} \pm 3.11$ & $1466.60^{\mathrm{a}} \pm 4.73$ \\
\hline Control & 50 & $116.40^{\mathrm{b}} \pm 0.62$ & $411.40^{\mathrm{b}} \pm 2.15$ & $882.80^{\mathrm{b}} \pm 17.8$ & $1487.30^{\mathrm{ab}} \pm 19.99$ \\
T1 & 60 & $115.00^{\mathrm{b}} \pm 0.50$ & $434.20 \mathrm{~b}^{\mathrm{c}} \pm 0.34$ & $907.80 \mathrm{~b}^{\mathrm{c}} \pm 13.31$ & $1510.80^{\mathrm{bc}} \pm 13.82$ \\
T2 & 70 & $114.80^{\mathrm{b}} \pm 0.62$ & $441.80^{\mathrm{c}} \pm 1.26$ & $938.50^{\mathrm{c}} \pm 4.99$ & $1549.30^{\mathrm{c}} \pm 5.75$ \\
T3 & 80 & $117.50^{\mathrm{b}} \pm 2.50$ & $456.00^{\mathrm{d}} \pm 3.78$ & $947.00^{\mathrm{d}} \pm 4.27$ & $1550.00^{\mathrm{c}} \pm 3.52$ \\
T4 & 90 & $111.80^{\mathrm{b}} \pm 2.76$ & $454.80^{\mathrm{d}} \pm 2.73$ & $948.00^{\mathrm{d}} \pm 2.85$ & $1562.50^{\mathrm{d}} \pm 3.85$ \\
T5 & 100 & $114.30^{\mathrm{b}} \pm 2.49$ & $454.30^{\mathrm{d}} \pm 1.75$ & $955.30^{\mathrm{e}} \pm 1.93$ & $1572.80^{\mathrm{e}} \pm 1.50$ \\
T6 & & & & & \\
\hline
\end{tabular}

Mean of ten observations

Mean* values bearing different superscript in a same column differ significantly $(\mathrm{p}<0.05)$ 
Table 4. Weekly body weight gain $(\mathrm{g})(\mathrm{Mean} * \pm \mathrm{SE})$ in broilers as influenced by various levels of calcium phosphate nanoparticles

\begin{tabular}{lccccc}
\hline \multirow{2}{*}{$\begin{array}{l}\text { Treatment } \\
\text { groups }\end{array}$} & $\begin{array}{c}\text { Inclusion level of } \\
\text { Calcium phosphate } \\
\text { nanoparticles (\%) }\end{array}$ & \multicolumn{3}{c}{ Body weight gain $(\mathrm{g}) /$ week $\left(\right.$ Mean $\left.{ }^{*} \pm \mathrm{SE}\right)$} \\
\cline { 3 - 6 } & 0 & $72.30^{\mathrm{a}} \pm 4.42$ & $260.90^{\mathrm{a}} \pm 10.64$ & $569.90^{\mathrm{a}} \pm 27.64$ & $891.60^{\mathrm{a}} \pm 48.16$ \\
\hline Control & 50 & $100.10^{\mathrm{b}} \pm 1.83$ & $351.40^{\mathrm{b}} \pm 4.50$ & $717.00^{\mathrm{b}} \pm 17.07$ & $1069.90^{\mathrm{b}} \pm 9.31$ \\
T1 & 60 & $103.60^{\mathrm{b}} \pm 5.33$ & $371.10^{\mathrm{b}} \pm 14.46$ & $728.30^{\mathrm{b}} \pm 19.92$ & $1068.50^{\mathrm{b}} \pm 36.51$ \\
T2 & 70 & $97.30^{\mathrm{b}} \pm 2.05$ & $336.10^{\mathrm{b}} \pm 13.38$ & $700.90^{\mathrm{b}} \pm 25.18$ & $1020.40^{\mathrm{ab}} \pm 57.20$ \\
T3 & 80 & $99.00^{\mathrm{b}} \pm 1.92$ & $362.00^{\mathrm{b}} \pm 4.82$ & $725.50^{\mathrm{b}} \pm 22.39$ & $1014.50^{\mathrm{ab}} \pm 18.51$ \\
T4 & 90 & $95.10^{\mathrm{b}} \pm 3.34$ & $330.60^{\mathrm{b}} \pm 12.97$ & $729.00^{\mathrm{b}} \pm 26.61$ & $984.20^{\mathrm{ab}} \pm 27.65$ \\
T5 & 100 & $104.20^{\mathrm{b}} \pm 4.16$ & $355.30^{\mathrm{b}} \pm 10.27$ & $713.10^{\mathrm{b}} \pm 19.63$ & $983.70^{\mathrm{ab}} \pm 40.27$ \\
\hline T6 & & & & & She \\
\hline
\end{tabular}

Mean of ten observations

Mean* values bearing different superscript in a same column differ significantly $(p<0.05)$

Table 5. Weekly feed efficiency (Mean* $*$ SE) as influenced by various levels of calcium phosphate nanoparticles in broilers fed upto 4 weeks

\begin{tabular}{lccccc}
\hline Treatment & Inclusion level of & \multicolumn{4}{c}{ Feed Conversion Ratio $\left(\mathrm{Mean}^{\star} \pm\right.$ SE) } \\
\cline { 3 - 6 } & $\begin{array}{c}\text { Calcium phosphate } \\
\text { nanoparticles (\%) }\end{array}$ & First week & Second week & Third week & Fourth week \\
\hline Control & 0 & $1.21^{\mathrm{NS}} \pm 0.08$ & $1.35^{\mathrm{NS}} \pm 0.06$ & $1.44^{\mathrm{b}} \pm 0.07$ & $1.64^{\mathrm{b}} \pm 0.08$ \\
$\mathrm{~T} 1$ & 50 & $1.17^{\mathrm{NS}} \pm 0.02$ & $1.17^{\mathrm{NS}} \pm 0.02$ & $1.23^{\mathrm{a}} \pm 0.03$ & $1.39^{\mathrm{a}} \pm 0.02$ \\
$\mathrm{~T} 2$ & 60 & $1.12^{\mathrm{NS}} \pm 0.05$ & $1.23^{\mathrm{NS}} \pm 0.05$ & $1.25^{\mathrm{ab}} \pm 0.04$ & $1.42^{\mathrm{ab}} \pm 0.05$ \\
$\mathrm{~T} 3$ & 70 & $1.18^{\mathrm{NS}} \pm 0.03$ & $1.32^{\mathrm{NS}} \pm 0.06$ & $1.34^{\mathrm{ab}} \pm 0.04$ & $1.52^{\mathrm{ab}} \pm 0.08$ \\
$\mathrm{~T} 4$ & 80 & $1.19^{\mathrm{NS}} \pm 0.04$ & $1.26^{\mathrm{NS}} \pm 0.02$ & $1.25^{\mathrm{ab}} \pm 0.04$ & $1.53^{\mathrm{ab}} \pm 0.02$ \\
$\mathrm{~T} 5$ & 90 & $1.18^{\mathrm{NS}} \pm 0.05$ & $1.33^{\mathrm{NS}} \pm 0.05$ & $1.41^{\mathrm{ab}} \pm 0.06$ & $1.59^{\mathrm{ab}} \pm 0.05$ \\
$\mathrm{~T} 6$ & 100 & $1.10^{\mathrm{NS}} \pm 0.03$ & $1.28^{\mathrm{NS}} \pm 0.04$ & $1.34^{\mathrm{ab}} \pm 0.04$ & $1.60^{\mathrm{ab}} \pm 0.07$ \\
\hline
\end{tabular}

Mean of ten observations

Mean* values bearing different superscript in a same column differ significantly $(\mathrm{p}<0.05)$

gain. Broiler chicks fed with different inclusion levels of calcium phosphate nanoparticles gained significantly $(\mathrm{p}<0.05)$ higher weight gain during their first week of age, compared with control birds. Similarly, body weight gain was found to be significantly $(\mathrm{p}<0.05)$ higher in case of birds fed with different levels of calcium phosphate nanoparticles compared to control up to third week of age. However, the cumulative gain in body weight of broiler chicken in the fourth week revealed that there was no significant difference in weight gain between birds fed with control feed and birds fed with rations containing 70, 80, 90 and 100 per cent of calcium phosphate nanoparticles. Thus, at the end of fourth week birds fed with $50 \%$ and $60 \%$ calcium phosphate nanoparticles had significantly $(\mathrm{p}<0.05)$ higher body weight gain. However, supplementation of calcium phosphate nanoparticles resulted increase in body weight gain over the control and the optimal gain recorded at 50 $\%$. Further increase in nanoparticle nutrient concentration did not favoured for further increase. However at all level of nanoparticle substitution in test group recorded higher body weight compared to control. Espinoza ${ }^{8}$ recorded that an excessive amount of fine particles will cause generally low and erratic intakes, digestive upsets, and poor performance. Thus the inversely proportional body weight gain to calcium phosphate nanoparticles supplementation could be attributed to incremental increase in fine particles in the feed.

The data on mean Feed Conversion Ratio (FCR) in broilers on weekly intervals as influenced by various levels of calcium phosphate nanoparticles is presented in Table 
5. The mean FCR in broilers in the control group was comparable to the data recorded by ${ }^{7,9}$.There was no significant difference in FCR during first and second week among the various treatments. However, beyond second week of age, the treatment containing $50 \%$ calcium phosphate nanoparticles had the better FCR that was significantly $(\mathrm{p}<0.05)$ different from control, but was statistically comparable to the rest of the treatments containing ascending order of graded level of calcium phosphate nanoparticles.

Increase in the inclusion level of calcium phosphate nanoparticles result in undesirable increase in feed efficiency in spite of being more palatable. It could be attributed to the digestive upset caused by corresponding increase in inclusion level of calcium phosphate nanoparticles. Weiss et al. ${ }^{10}$ recorded that nanoparticle-sized ingredients might increase the functionality or bioavailability of ingredients and nutrients, and thereby minimise the concentrations needed in the food product. Desai et al. ${ }^{1}$ observed that nano form of supplementation increases surface area which possibly could increase absorption and thereby utilization of minerals leading to reduction in the quantity of supplements and ultimately reduction in feed cost. The desirable FCR recorded in birds fed with containing $50 \%$ calcium phosphate nanoparticles may be due to the above two observations and any further increase in inclusion level of calcium phosphate nanoparticles result in undesirable effect.

\section{Conclusion}

Feeding of calcium and phosphorus minerals as calcium phosphate nano particles instead of conventional dicalcium phospahate has increased the feed efficiency among broiler chickens. The demand of phosphorous and calcium nutrients as nanoparticles has reduced the quantum of such nutrient requirement as conventional feed form (di-calcium phospahate) may favour for minimizing the cost incurred on feed transport.

\section{References}

1. Desai MP, Labhasetwar V, Walter E, Levy RJ, Amidon GL. The mechanism of uptake of biodegradable microparticles in Caco-2 cells is size dependent. Pharm Res. 1997; 14:1568-73.

2. Waldroup PW. Nutritional approaches to reducing phosphorus excretion by poultry. Poult Sci. 1999; 78:683-91.

3. Sokolova VV, Radtke I, Heumann R, Epple M. Effective transfection of cells with multi-shell calcium phosphateDNA nanoparticles. Biomaterials. 2006; 27:3147-53.

4. Bisht S, Bhakta G, Mitra S, Maitra A. pDNA loaded calcium phosphate nanoparticles: highly efficient non-viral vector for gene delivery. I J Pharm. 2005; 288: 157-68.

5. Food Safety Authority of Ireland. The relevance for food safety of applications of nanotechnology in the food and feed industries. Dublin I: Food Safety Authority of Ireland; 2008.

6. Ahmad T, Rasool S, Sarwar M, Haq A.-ul, Hasan Z.-ul. Effect of microbial phytase produced from a fungus Aspergillusniger on bioavailability of phosphorus and calcium in broiler chickens. Anim Feed Sci. Technol. 2000; 83:103-14.

7. Saima MZUK, Jabbar MA, Ijazand M, Qadeer MA. Efficacy of microbial phytase at different levels on growth performance and mineral availability in broiler chicken. The Journal of Animal \& Plant Sciences. 2009; 19(2):58-62.

8. Espinoza. Wheat gone bad? Here's how to use it as alternative animal feed; 2011. Available from: http;//extension.osu. edu/new-releases/archives/

9. Yan F, Angel R, Ashwell C, Mitchell A, Christman M. Evaluation of the Broiler's Ability to Adapt to an Early Moderate Deficiency of Phosphorus and Calcium. Poult Sci. 2005; 84:1232-41.

10. Weiss J, Takhistov P, McClements J. Functional Materials in food Nanotechnology. J Food Sci.2006; 71(9):107-16. 